\title{
Nexus between Stock Market Returns and Economic Variables: Evidence from India
}

\author{
Vanitha Chawla* and Shweta**
}

\begin{abstract}
The paper examines the impact of selected macroeconomic variables on the Indian stock market. The macroeconomic variables used in the study are interest rate, exchange rate, index of industrial production (IIP) and gold price. BSE Sensex is used as proxy for Indian stock market. We have used the monthly data for all the variables from January 2001 to December 2016. Regression analysis and Granger Causality test is used to establish the relationship between the stock market and macroeconomic variables. The results show significant impact of only exchange rate on stock returns. All the other variables have shown insignificant impact on the stock market returns. The results of Granger causality test show unidirectional relationship between exchange rate and stock prices and bi-directional relation between IIP and SENSEX.
\end{abstract}

Keywords: Stock market; Interest rate; Index of Industrial Production (IIP); Exchange rate; BSE Sensex; Granger Causality.

\subsection{Introduction}

Stock markets are most vital component of any economy. It provides companies with access to capital their growth and expansion. The stock prices of the companies get affected by many macroeconomic factors. With the knowledge of these factors and their impact on the stock prices the market participants can make better decisions. Understanding of these relationships in depth is important for the policy makers also.

The relation between macroeconomic variables and stock prices has different theoretical frameworks such as Efficient Market Hypothesis (EMH) and Arbitrage Pricing Theory.

*Assistant Professor, Department of Commerce, Shivaji College, University of Delhi, Delhi, India. (Email id: vanitha_2182@yahoo.co.in)

**Corresponding author; Assistant Professor, Department of Commerce, Shivaji College, University of Delhi, Delhi, India. (Email id: shweta.shweta.gautam@gmail.com) 
The term 'market efficiency' explains the relationship between information and share prices in the capital market. Market efficiency influences the investment strategy of an investor because in an efficient market, there would be no undervalued or overvalued stocks. This implies that the stocks will not yield returns higher than the deserved expected returns, given their risk. This theory of EMH was given by Eugene Fama in 1970. In contradiction to the EMH there is evidence that key macroeconomic variables can be used to predict the behaviour of stock market returns.

The second theory is the Arbitrage Pricing theory (APT) which states that the returns on the financial assets can be modelled as a linear function of various macroeconomic factors or theoretical market indices where sensitivity to changes of various factors is given by the beta coefficients. The theory of Arbitrage Pricing was developed by Ross (1976). The Capital Asset Pricing Model can be considered as a special case of APT, where asset prices depend on single factor market performance. In APT the factors which can affect asset prices are not explicitly given. Moreover these factors can change in number and over time for different economies. Later on Roll and Ross (1980) in their study found "at least three and probably four factors" that affect asset prices using data of individual equities for the period 1962-1972. These factors are unanticipated changes in inflation, industrial production, risk-premiums and in the slope of term structure of interest rates. Numerous studies have been conducted for the Indian stock markets for different time periods and have given different results. Tripathi \& Kumar (2015) results show negative impact of interest rate Indian stock returns while, Singh (2016) suggest positive impact of interest rate and negative impact of industrial production. Pramod \& Puja (2012), have reported positive influence of industrial production.Baranidharan (2016), Tripathi \& Kumar (2015) and Singh (2016) have all reported negative impact of exchange rate on Indian stock markets. Pal \& Mittal (2011) also show positive interest rate impact for the Indin markets. The present paper attempts to investigate the impact of these variables in Indian markets.

\subsection{Literature Review}

This section reviews existing studies that have examined the relation of stock market returns with different types of macroeconomic variables. Aijaz et al (2016) have studied the impact of gold prices and crude oil prices on Pakistan Stock exchange. Their results show significant positive impact of gold prices on the stock exchange through regression analysis. The crude oil prices do not show any significant impact. Baranidharan (2016) has examined the impact of different exchange rates on Indian stock exchange. The exchange rates used for analysis are US dollar, Pound, Euro, Yen. 
The results indicate that the exchange rates have significant impact on the BSE Sensex both in the long run and short run using cointegration, VAR and causality techniques.

Pilinkus \& Boguslauskas (2015) find that gross domestic product and money supply have a strong positive influence on stock market prices in the short run while unemployment rate, exchange rate, short-term interest rates cause opposite movements for stock prices for Lithuanian stock market.

Plachý \& Rasovec (2015) have investigated the impact of GDP, inflation, interest rate, rate of unemployment, value of export and value of import on the stock prices of selected 20 countries. These countries have been divided into clusters. The cluster of large developed countries shows significant impact of interest rate on the stock prices. Tripathi \& Kumar (2015) study the impact of GDP, inflation, interest rate, exchange rate, money supply and oil prices on the stock markets of BRICS economies. The results suggest that GDP and inflation do not have significant impact on any of these markets. The study has found significant negative impact of interest rate, exchange rate and oil prices and positive impact of money supply on the stock prices. Suganthi and Dharshanaa (2014) observe that there is a bidirectional relationship between FII and Sensex, FII and Exchange Rate. Similarly there is unidirectional relationship between Sensex and IIP, Sensex and WPI, FII and IIP \& FII and Exchange Rate but no relationship is found between FII and WPI by using Correlation and Granger causality test.

Gupta and Reid (2013) have analysed the impact of wide range of unanticipated macroeconomic surprises on the stock prices of selected industry specific indices of South Africa. Their result suggests that the gold mining index and monetary surprise negatively impacts the stock prices. Ahmad et al. (2012) find that there is significant negative impact of inflation and exchange rate on stock prices but the impact of economic growth is positive but weak on stock prices for Karachi stock exchange by using ARIMA model. Zakaria and Shamsuddin (2012), evaluated that only money supply volatility is significantly positively related to stock market volatility and there is weak connection between other variables with respect to stock market volatility.

Ray and Vani (2012) analyse that macroeconomic variables namely the interest rate, output, money supply, inflation rate and the exchange rate influence stock market but the impact of other variables such as fiscal deficit, and FII are negligible on the stock market by using modern non-linear technique like VAR and Artificial Neural Network. Srinivasan (2011) suggests that there is significant negative long-run relationship between NSE-Nifty share price index and certain crucial macroeconomic variables like index of industrial production, money supply, interest rate, exchange rate, consumer price index and the US stock price index by using co-integration technique. Similarly 
short run causality is found between NSE-Nifty share price index and certain monetary variables like money supply and interest rate, inflation and money supply, and the US stock market and exchange rate by using multivariate vector error correction model.

Mashayekh et al. (2011) analyse the impact of macroeconomic variables namely interest rate, inflation rate, and exchange rate on stock returns in Pakistan which established a weak connection between macroeconomic variables and stock market returns during the period of January 2007 to December 2012 by using multiple regression analysis. All the three variables indicate insignificant relationship with stock returns. Menike (2010) explore the negative relationship between inflation rate, exchange rate, and interest rate with respect to Colombo stock exchange whereas money supply is positively related to stock return. Hussaine and Khanh (2009) examine that industrial production has a positive effect on Vietnamese stock prices. Hence there are statistically significant relationship among the domestic production sector, money markets, and stock prices in Vietnam.

Kaur (2009) investigate that SENSEX Granger causes per capita GNP, bank rate, money supply and WPI. But these variables or even other real economic variables does not Granger causes SENSEX, which state that real sector is not influencing stock market. Cota et al. (2008) use cointegration and causality techniques to indicate that the domestic economic activity, measured through industrial production has significant impact on stock markets and international factors have no major impact in the long run. Kwon et al. (1997), show in their study that inflation and interest rates do not significantly impact the stock prices in the Korean stock markets. The Korean stock prices are affected by the real economic factors.

\subsection{Objectives and Hypothesis}

The objective of this paper is to study the impact of selected macroeconomic variables on the Indian stock market. The macroeconomic variables selected are Wholesale Price Index (WPI), Index for Industrial Production (IIP), Money Supply (M3), Treasury Bill Rate (T Bills), and Exchange Rate (FORX). BSE SENSEX is used as the proxy for the Indian stock market. The WPI is used as proxy for inflation, broad money measure M3 is proxy for money supply, T Bills rate is used to proxy for interest rate and IIP is used for industrial production.

The following are the Null Hypothesis for the study:

1. $\mathrm{H}_{0}$ : There is no significant relation between exchange rate and Indian stock market.

2. $\mathrm{H}_{0}$ : There is no significant relation between gold prices and Indian stock market.

3. $\mathrm{H}_{0}$ : There is no significant relation between interest rate and Indian stock market. 
4. $\mathrm{H}_{0}$ : There is no significant relation between industrial production and Indian stock market.

\subsection{Data and Methodology}

\subsection{Description of variables}

The following section describes the dependent and the independent variables used in the study.

\subsubsection{Dependent variable}

$S \& P$ BSE SENSEX: The S\&P BSE SENSEX is a free-float market weighted stock market index. It consists of 30 well established and financially sound companies listed on BSE. The companies that have largest trading volume are selected for the index and cover all the major sectors of the economy.

\subsubsection{Independent variables}

Foreign exchange rate (FORX): The first macroeconomic variable used for the study is exchange rate which is the used as bilateral nominal rate of exchange of Indian Rupees against one unit of Foreign currency US Dollars. Whenever there is an increase in exchange rate it has a negative impact on the stock market because of inflation. The importer companies are badly affected by the depreciating currency and have lower earnings and lower share prices. However this benefits the exporter companies as they receive more Rupees per Dollar which increases their earnings and share prices. Impact of the exchange rate on the stock market can be positive or negative depending upon the overall impact on the domestic exporting and the importing company. Mohi-u-Din and Mubasher (2013) have shown in their study negative impact of exchange rate on stock market in India.

Index of Industrial Production (IIP): Index of Industrial Production (IIP) is an index which measures the growth of various sectors of the economy such as mining, manufacturing, electricity etc. The index indicates the short term changes in the volume of production of the basket of industries over a period of time in relation to the base period chosen. An increase in the index shows expansion of the industrial output which suggests higher earning and share prices for the firms. Fama (1990) in his study suggested the positive relation between industrial production and stock markets Interest rate (IR): The Treasury bill rate has been used as proxy for the interest rate for this study. The treasury bills are money market instrument which is a market for short term funds. The impact of rising interest rate is negative on the stock market. High 
interest rates increases the opportunity cost of holding money, increases cost of borrowing for the companies. Momani and Alsharari (2012), in their paper on Amman stock exchange indicated negative impact of interest rate on the stock market.

Gold prices: Raza et al. (2016) have studied the relation of gold prices and stock market returns. Their results show that gold work as a hedge against inflation. During high inflation the stock markets give negative returns. Thus in the short run gold investment protect the investors from the extreme negative stock market shocks. This relation does not hold in the long run.

\subsection{Methodology}

The data for the variables has been collected from Yahoo finance and RBI website. For the analysis monthly data is collected for the period from January 2001 to December 2016.

To test the relationship between the macroeconomic variables and the Sensex two models are used namely Ordinary Least Squares (OLS) and Granger Causality Test is used to find relation between individual independent variables and dependent variable. The time series data is assumed to be non-stationary and it is necessary to test the variables for the stationarity before OLS estimation. If non-stationary data is used for analysis it shows high $\mathrm{R}^{2}$ but it will lead to spurious regression results. The stationarity of the variables is tested with Augmented Dickey Fuller test. If the results at level show non-stationarity then first difference will be taken before applying the OLS method and granger causality test. The multivariate regression model used to test the relation between sensex and macroeconomic variables is as follows (all the variables are transformed into the logarithmic form):

$\operatorname{DLog}($ SENSEX $)=\alpha_{1}+\beta_{1}$ DLog(INTEREST_RATE $)+\beta_{2}$ DLog $($ FORX $)+\beta_{3}$ DLog(IIP $)+$ $\beta_{4} \operatorname{DLog}($ GOLD_PRICE $)+\varepsilon_{\mathrm{it}}$

\subsection{Empirical Results}

\subsection{Descriptive statistics}

Table 1 provides the descriptive statistics regarding the variables under study. As can be seen from the Table 1, all the variables are asymmetrical. The Sensex, IIP, interest rate and gold price have negative skewness which indicates fat and long tails at the left side of the distribution. Kurtosis of all the variables also shows that the variables are not normally distributed as value of kurtosis of all the variables is less than 3 . This indicates that the variables have platykurtic distribution and there is less probability of extreme values. The null hypothesis of the Jarque bera test is a joint hypothesis of 
skewness being zero and the excess kurtosis being zero. The $\mathrm{p}$ value of all the variables suggest normality rest all variables are not random.

Table 1: Descriptive Statistics

\begin{tabular}{|l|l|c|c|l|c|}
\hline & $\begin{array}{l}\text { Log } \\
\text { (Sensex) }\end{array}$ & Log (Forx) & $\begin{array}{l}\text { Log } \\
\text { (Gold_price) }\end{array}$ & $\begin{array}{l}\text { Log } \\
\text { (IIP) }\end{array}$ & $\begin{array}{l}\text { Log } \\
\text { (Interest_rate) }\end{array}$ \\
\hline Mean & 9.366139 & 3.909127 & 10.55835 & 4.888445 & 1.84734 \\
\hline Median & 9.659406 & 3.852804 & 10.62411 & 4.999438 & 1.907767 \\
\hline Maximum & 10.28261 & 4.228263 & 11.46239 & 5.291796 & 2.410603 \\
\hline Minimum & 7.941509 & 3.668549 & 9.407176 & 4.316335 & 1.136518 \\
\hline Std. Dev. & 0.722332 & 0.151007 & 0.682528 & 0.298152 & 0.274451 \\
\hline Skewness & -0.660415 & 0.727084 & -0.206278 & -0.5725 & -0.70116 \\
\hline Kurtosis & 2.06726 & 2.358103 & 1.50341 & 1.851383 & 2.894461 \\
\hline Jarque-Bera & 20.91676 & 20.2131 & 19.27987 & 21.0427 & 15.82116 \\
\hline Probability & 0.000029 & 0.000041 & 0.000065 & 0.000027 & 0.000367 \\
\hline Sum & 1798.299 & 750.5524 & 2027.202 & 938.5815 & 354.6892 \\
\hline $\begin{array}{l}\text { Sum Sq. } \\
\text { Dev. }\end{array}$ & 99.65687 & 4.355419 & 88.97628 & 16.97887 & 14.38674 \\
\hline Observations & 192 & 192 & 192 & 192 & 192 \\
\hline
\end{tabular}

\subsection{Unit root test}

To test the stationarity of the variables unit root test is conducted. Augmented Dickey Fuller test is used test the unit root in the variables

The equation for $\mathrm{ADF}$ test is as follows:

$\Delta \mathrm{Y}_{\mathrm{t}}=\beta_{1}+\beta_{2} \mathrm{t}+\delta \mathrm{Y}_{\mathrm{t}-1}+\sum \alpha_{\mathrm{i}} \Delta \mathrm{Y}_{\mathrm{t}-1}+\varepsilon_{\mathrm{t}}$

The null and alternate hypotheses of the unit root test are as follows:

$\mathrm{H}_{0}: \delta=0$ Unit root (Variable is non-stationary)

$\mathrm{H}_{1}: \delta<0$ No Unit root (Variable is stationary)

The results of ADF test at Level are shown in Table 2. The results of the ADF test at level shows that all the variables are non-stationary at level as $\mathrm{p}$ values for the variables is higher than the 0.05 , therefore we do not reject the null hypothesis and conclude that variables are non-stationary. Now we need to test the variables at first difference for stationarity. The results of ADF test at first difference are shown in the Table 3. At $1 \%$ significance level the results of ADF test indicate that the variables are stationary at first difference. So we reject the null hypothesis and the variables are ready for conducting the OLS. 
Table 2: ADF Test Results at Level (Constant and Trend)

\begin{tabular}{|l|c|l|l|}
\hline Variables & P value & Comments & Results \\
\hline Log(BSE_SENSEX) & 0.7868 & Do not reject H0 & BSE_SENSEX is non-stationary \\
\hline $\log ($ FORX $)$ & 0.8412 & Do not reject H0 & FORX is non-stationary \\
\hline Log(GOLD_PRICE) & 0.9793 & Do not reject H0 & GOLD_PRICE is non-stationary \\
\hline Log(IIP) & 0.9766 & Do not reject H0 & IIP is non-stationary \\
\hline Log(INTEREST_RATE) & 0.2728 & Do not reject H0 & $\begin{array}{l}\text { INTEREST_RATE is non- } \\
\text { stationary }\end{array}$ \\
\hline
\end{tabular}

Table 3: ADF Test Results at First Difference (Constant and Trend)

\begin{tabular}{|l|c|l|l|}
\hline Variables & P value & comments & Results \\
\hline DLog(BSE_SENSEX) & 0.0000 & Reject the H0 & BSE_SENSEX is stationary \\
\hline DLog(FORX) & 0.0000 & Reject the H0 & FORX is stationary \\
\hline DLog(GOLD_PRICE) & 0.0000 & Reject the H0 & GOLD_PRICE is stationary \\
\hline DLog(IIP) & 0.0458 & Reject the H0 & IIP is stationary \\
\hline DLog(INTEREST_RATE) & 0.0000 & Reject the H0 & INTEREST_RATE is stationary \\
\hline
\end{tabular}

\subsection{Regression output}

The OLS equation is as follows:

$\operatorname{DLog}($ SENSEX $)=\alpha_{1}+\beta_{1} \operatorname{DLog}($ INTEREST_RATE $)+\beta_{2} \operatorname{DLog}($ FORX $)+\beta_{3} \operatorname{DLog}($ IIP $)+$

where $\mathrm{D}$ is the first difference

$$
\beta_{4} \operatorname{DLog}\left(\mathrm{GOLD} \text { PRICE) }+\varepsilon_{\mathrm{it}}\right.
$$

The regression output is given in Table 4. The regression output shows significant relation between exchange rate and stock prices since the $\mathrm{p}$ value is less than 0.05. The negative sign of the coefficient of exchange rate indicates that when exchange rate increases (rupee depreciates) stock prices fall. This negative relation also supported by previous studies done for Indian stock market. All the other independent variables are not significant as there $\mathrm{p}$ values are higher than 0.05 .

\subsection{Analysis of residuals diagnostic}

Regression residuals are computed as difference between actual and estimated or fitted values. Each residual indicates the unpredicted variation of associated observation. After choosing regression variables and fitted or estimated regression model, it is relevant to plot residuals for ensuring the satisfaction of OLS assumption. Hence we need to check whether residuals are white noise or not which means that regression 
residuals do not include any systematic information. It is the indication that this information is not incorporated in our regression model.

Table 4: The Impact of Macroeconomic Variables on Indian Stock Market

\begin{tabular}{|c|c|c|c|c|}
\hline \multicolumn{5}{|c|}{ Dependent Variable: DLOG(BSE_SENSEX) } \\
\hline \multicolumn{5}{|l|}{ Method: Least Squares } \\
\hline \multicolumn{5}{|c|}{ Included observations: 191 after adjustments } \\
\hline Variable & Coefficient & Std. Error & t-Statistic & Prob. \\
\hline $\mathrm{C}$ & 0.013489 & 0.004312 & 3.128438 & 0.002 \\
\hline $\begin{array}{l}\text { DLOG } \\
\text { (INTEREST_RATE) }\end{array}$ & 0.002317 & 0.039762 & 0.058276 & 0.9536 \\
\hline DLOG(FORX) & -1.647303 & 0.196152 & -8.398105 & 0 \\
\hline DLOG(IIP) & -0.004752 & 0.074709 & -0.063608 & 0.9494 \\
\hline DLOG(GOLD_PRICE) & -0.068105 & 0.107769 & -0.631955 & 0.5282 \\
\hline R-squared & 0.288505 & Mean dependent var & & 0.009514 \\
\hline Adjusted R-squared & 0.273204 & S.D. dependent var & & 0.067586 \\
\hline F-statistic & 18.85536 & Durbin-Watson stat & & 1.835453 \\
\hline Prob (F-statistic) & 0 & & & \\
\hline
\end{tabular}

\subsubsection{Correlogram for the residuals}

Table 5 is the eviews output of correlogram for the residuals ensuring that there is no pattern in SAC or SPAC indicating the robustness of the results.

\subsubsection{Serial correlation LM test}

The presence of serial correlation is tested by using Breusch-Godfrey Serial Correlation LM Test. The following hypothesis is used to check the Residuals for OLS. $\mathrm{H}_{0}$ : No Autocorrelation $\mathrm{H}_{1}$ : Autocorrelation

Table 6 is the eviews output of Breusch-Godfrey Serial Correlation LM Test. It is indicating that we cannot reject the null hypotheses as the p-value is $36.80 \%$ which is higher than critical value at $5 \%$. As a result we conclude that there is no autocorrelation.

\subsubsection{Heteroscedasticity test}

It is relevant to ensure the robustness of OLS output as we cannot depend upon OLS output in the presences of heteroscedasticity. 
Table 5: Correlogram for the Residuals

Sample: 2001M01 2016M12

Included observations: 191

Q-statistic probabilities adjusted for 4 dynamic regressors

\begin{tabular}{|c|c|c|c|c|c|c|}
\hline Autocorrelation & Partial Correlation & & $\mathrm{AC}$ & PAC & Q-Stat & Prob* \\
\hline$.\left.\right|^{*} \quad \mid$ & $.^{*} \quad \mid$ & 1 & 0.081 & 0.081 & 1.2636 & 0.261 \\
\hline.$\quad 1$ & $.1 . \quad 1$ & 2 & 0.070 & 0.064 & 2.2152 & 0.330 \\
\hline .1 &. & 3 & 0.040 & 0.030 & 2.5272 & 0.470 \\
\hline .1 &. & 4 & 0.043 & 0.034 & 2.8928 & 0.576 \\
\hline$*||$. & $* \mid$ & 5 & -0.101 & -0.112 & 4.9020 & 0.428 \\
\hline$*|\quad|$ &. & 6 & -0.074 & -0.066 & 5.9840 & 0.425 \\
\hline .1 &. & 7 & -0.062 & -0.042 & 6.7561 & 0.455 \\
\hline$*|. \quad|$ & $* \mid$ & 8 & -0.145 & -0.126 & 10.986 & 0.203 \\
\hline .1 &. & 9 & 0.002 & 0.043 & 10.987 & 0.277 \\
\hline .1 &. & 10 & 0.032 & 0.047 & 11.194 & 0.343 \\
\hline .1 &. & 11 & -0.030 & -0.039 & 11.384 & 0.412 \\
\hline$.\left.\right|^{*} \quad \mid$ & $.^{*} \quad \mid$ & 12 & 0.096 & 0.099 & 13.291 & 0.348 \\
\hline .1 & $.1 . \quad 1$ & 13 & 0.049 & 0.002 & 13.783 & 0.389 \\
\hline .1 & .1 & 14 & -0.017 & -0.053 & 13.841 & 0.462 \\
\hline .1 &. & 15 & -0.035 & -0.039 & 14.090 & 0.519 \\
\hline.$|\quad|$ &. $\mid 1$ & 16 & -0.029 & -0.055 & 14.264 & 0.579 \\
\hline *. | & *. | & 17 & -0.106 & -0.080 & 16.639 & 0.479 \\
\hline.$|\quad|$ &. & 18 & 0.003 & 0.055 & 16.640 & 0.548 \\
\hline$.\left.\right|^{*} \mid$ & $.\left.\right|^{*} \quad \mid$ & 19 & 0.129 & 0.150 & 20.233 & 0.381 \\
\hline .1 & .1 & 20 & 0.045 & 0.060 & 20.660 & 0.417 \\
\hline $.1 . \quad \mid$ &. & 21 & 0.000 & -0.020 & 20.660 & 0.480 \\
\hline $.1 . \quad \mid$ & .1 & 22 & 0.031 & -0.035 & 20.865 & 0.529 \\
\hline .1 &. & 23 & -0.011 & -0.059 & 20.891 & 0.588 \\
\hline$.\left.\right|^{*} \quad \mid$ & $.^{*} \quad \mid$ & 24 & 0.082 & 0.087 & 22.362 & 0.558 \\
\hline .1 & .1 & 25 & 0.059 & 0.061 & 23.137 & 0.570 \\
\hline$*|\quad|$ & *| | & 26 & -0.113 & -0.107 & 26.014 & 0.462 \\
\hline$* \mid$ & *| | & 27 & -0.130 & -0.081 & 29.833 & 0.322 \\
\hline$*|\quad|$ & $*|\quad|$ & 28 & -0.104 & -0.099 & 32.280 & 0.263 \\
\hline.$|\quad|$ &.$|\quad|$ & 29 & -0.004 & 0.044 & 32.284 & 0.308 \\
\hline$*|\quad|$ & .1 & 30 & -0.090 & -0.027 & 34.122 & 0.276 \\
\hline. $\mid 1$ & $* 1$ & 31 & -0.047 & -0.076 & 34.624 & 0.299 \\
\hline $.1 . \quad \mid$ &. $\mid 1$ & 32 & 0.050 & 0.047 & 35.199 & 0.319 \\
\hline .1 & $.1 . \quad \mid$ & 33 & 0.049 & 0.036 & 35.766 & 0.340 \\
\hline.$|\quad|$ &. $\mid 1$ & 34 & 0.009 & -0.041 & 35.787 & 0.385 \\
\hline $.1 . \quad \mid$ & $.1 . \quad 1$ & 35 & 0.054 & 0.048 & 36.475 & 0.400 \\
\hline .1 & .1 & 36 & 0.024 & -0.005 & 36.612 & 0.440 \\
\hline
\end{tabular}

*Probabilities may not be valid for this equation specification. 
80 | MUDRA: Journal of Finance and Accounting, Volume 4, Issue 1, Jan-Jun 2017

Table 6: Breusch-Godfrey Serial Correlation LM Test

\begin{tabular}{|l|c|l|l|c|}
\hline F-statistic & 1.005137 & Prob. F(2,184) & & 0.368 \\
\hline Obs*R-squared & 2.064199 & Prob. Chi-Square(2) & & 0.3563 \\
\hline Variable & Coefficient & Std. Error & t-Statistic & Prob. \\
\hline C & 0.00012 & 0.004314 & 0.027772 & 0.9779 \\
\hline DLOG(INTEREST_RATE) & -0.003586 & 0.039935 & -0.089792 & 0.9285 \\
\hline DLOG(FORX) & -0.012672 & 0.196352 & -0.064536 & 0.9486 \\
\hline DLOG(IIP) & -0.010653 & 0.076017 & -0.14014 & 0.8887 \\
\hline DLOG(GOLD_PRICE) & -0.008932 & 0.108045 & -0.082665 & 0.9342 \\
\hline RESID(-1) & 0.078378 & 0.075109 & 1.043527 & 0.2981 \\
\hline RESID(-2) & 0.064166 & 0.074158 & 0.865261 & 0.388 \\
\hline F-statistic & 0.335046 & Durbin-Watson stat & & 2.003337 \\
\hline Prob(F-statistic) & 0.917757 & & & \\
\hline
\end{tabular}

The following hypothesis is used to check the Residuals for OLS.

$\mathbf{H}_{\mathbf{0}}$ : No heteroscedasticity

$\mathbf{H}_{\mathbf{1}}$ : Heteroscedasticity

Table 7 is the eviews output of Breusch-Pagan-Godfrey Heteroskedasticity Test. It is indicating that we cannot reject the null hypotheses as the p-value is $27.80 \%$ which is higher than critical value at $5 \%$. As a result we conclude that there is no Heteroscedasticity indicating robustness of the results.

Table 7: Heteroskedasticity Test: Breusch-Pagan-Godfrey

\begin{tabular}{|l|c|c|c|c|}
\hline F-statistic & 1.283626 & Prob. F(4,186) & & 0.278 \\
\hline Obs*R-squared & 5.130889 & Prob. Chi-Square(4) & & 0.2741 \\
\hline Scaled explained SS & 7.633716 & Prob. Chi-Square(4) & & 0.106 \\
\hline Variable & Coefficient & Std. Error & t-Statistic & Prob. \\
\hline C & 0.003033 & 0.000428 & 7.07913 & 0 \\
\hline DLOG(INTEREST_RATE) & -0.00578 & 0.003951 & -1.463179 & 0.1451 \\
\hline DLOG(FORX) & 0.018614 & 0.019489 & 0.955109 & 0.3408 \\
\hline DLOG(IIP) & 0.003431 & 0.007423 & 0.462225 & 0.6445 \\
\hline DLOG(GOLD_PRICE) & 0.014145 & 0.010708 & 1.321023 & 0.1881 \\
\hline F-statistic & 1.283626 & Durbin-Watson stat & & 2.110824 \\
\hline Prob(F-statistic) & 0.277987 & & & \\
\hline
\end{tabular}




\subsubsection{Normality test}

It is important to ensure that whether the error term is following normal distribution or not. The following hypothesis is used to check the normality of error term.

$\mathbf{H}_{\mathbf{0}}$ : Residuals are normally distributed

$\mathbf{H}_{\mathbf{1}}$ : Residuals are not normally distributed

Table 8 is the 'eviews' output of Jarque Bera test and histogram of residuals. It is indicating that we can reject the null hypotheses as the p-value is 0.000048 which is lower than critical value at 5\% level. As a result we conclude that residuals are not following normal distribution. Although the residuals are following non-normally distribution, we can rely on our t-tests results as we are using reasonably large sample size in our linear regression model.

\section{Table 8: Histogram of residuals and Jarque-Bera test}

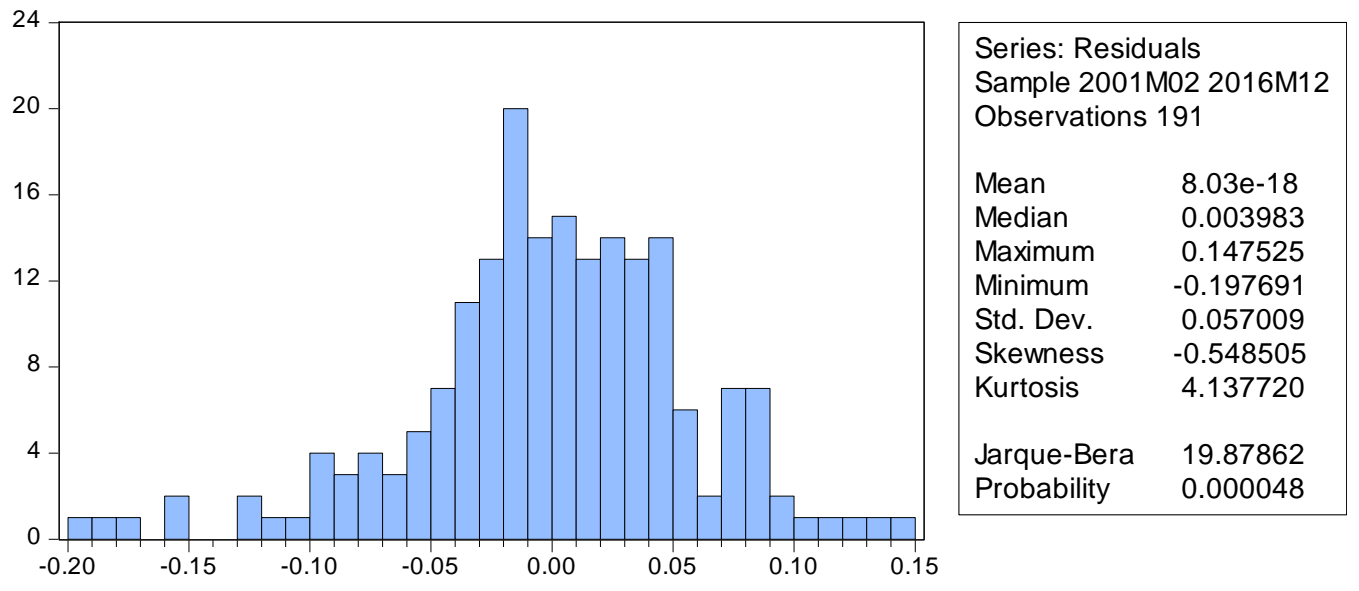

\subsection{Granger causality test}

Granger Causality is a statistical concept that is based on prediction. Its mathematical formulation is based on linear regression modelling stochastic processes (Granger 1969). A variable X granger causes Y if Y can be predicted better by the past values of both $\mathrm{X}$ and $\mathrm{Y}$. In the present study the granger causality test is used to find the causal relationship between selected macroeconomic variables and the stock prices. Table 9 shows the result of the Granger causality test with lags of 4 . The results of the Granger causality test suggest bidirectional relation between BSE_SENSEX and exchange rate at 5\% significance level. There is also unidirectional relation between interest rate and BSE_SENSEX, (interest rate Granger causes the BSE_SENSEX) we 
can reject the null hypothesis at 5\% significance level. The variables namely gold prices, industrial productions do not granger cause SENSEX. SENSEX does not granger cause gold prices and industrial production.

Table 9: Granger Causality Test for Relation between Macroeconomic Variables and SENSEX

\begin{tabular}{|l|l|l|l|}
\hline Null Hypothesis & Prob. & Results & Relationship \\
\hline $\begin{array}{l}\text { DLOG(FORX) does not Granger Cause } \\
\text { DLOG(BSE_SENSEX) }\end{array}$ & 0.0149 & Reject the $\mathrm{H}_{0}$ & Bi-directional \\
\hline $\begin{array}{l}\text { DLOG(BSE_SENSEX) does not Granger } \\
\text { Cause DLOG(FORX) }\end{array}$ & 0.003 & Reject the $\mathrm{H}_{0}$ & Bi-directional \\
\hline $\begin{array}{l}\text { DLOG(IIP) does not Granger Cause } \\
\text { DLOG(BSE_SENSEX) }\end{array}$ & 0.7582 & Do not reject the $\mathrm{H}_{0}$ & No Relation \\
\hline $\begin{array}{l}\text { DLOG(BSE_SENSEX) does not Granger } \\
\text { Cause DLOG(IIP) }\end{array}$ & 0.102 & Do not reject the $\mathrm{H}_{0}$ & No Relation \\
\hline $\begin{array}{l}\text { DLOG(GOLD_PRICE) does not Granger } \\
\text { Cause DLOG(BSE_SENSEX) }\end{array}$ & 0.6659 & Do not reject the $\mathrm{H}_{0}$ & No Relation \\
\hline $\begin{array}{l}\text { DLOG(BSE_SENSEX) does not Granger } \\
\text { Cause DLOG(GOLD_PRICE) }\end{array}$ & 0.4916 & Do not reject the $\mathrm{H}_{0}$ & No Relation \\
\hline $\begin{array}{c}\text { DLOG(INTEREST_RATE) does not } \\
\text { Granger Cause DLOG(BSE_SENSEX) }\end{array}$ & 0.0331 & Reject the $\mathrm{H}_{0}$ & Unidirectional \\
\hline $\begin{array}{l}\text { DLOG(BSE_SENSEX) does not Granger } \\
\text { Cause DLOG(INTEREST_RATE) }\end{array}$ & 0.2547 & Do not reject the $\mathrm{H}_{0}$ & No Relation \\
\hline
\end{tabular}

\subsection{Conclusion}

The present paper investigates the impact or selected macroeconomic variables on the stock markets. The empirical results of this study using OLS suggest that exchange rate affects the stock prices in Indian stock market. Most of the previous studies also confirm the similar analysis. All the other variables namely interest rate, gold price and industrial production do not significantly affect the stock prices. The results of Granger Causality test indicate bidirectional relation between exchange rate and the stock prices. The results also conclude that there is bi-directional relation between interest rate and SENSEX.

It is now relevant for the government to bring few amendments through stock market. It is also important to note that stock market cannot be taken as an indicator of financial health of an economy as results are clearly showing that many variables are not 
significantly related to stock market except exchange rate. There are other exogenous variables which are influencing stock returns. These variables are need be analysed closely to investigate the entire impact chain. Regulatory bodies and policy makers would use these inter relational analysis for solving economic issues. To develop more understanding of relationship between stock returns and economic variables, many other economic variables can be added in the model to bring more robust results.

\section{References}

Ahmad, Z., Ahmad, Z., Khan, M. S., \& Javaid, U. (2012). Capturing the stock price movements at Karachi Stock exchange: Are macroeconomic variables relevant? African Journal of Business Management, 6(8), 3026-3034.

Aijaz, U., Faisal, M.,\& Meraj, S. (2016). Impact of oil and gold prices on stock market index. Journal of Business Strategies, 10(2), 69-84.

Auzairy, N. A., Ahmad, R., \& Ho, C. S. (2011). Stock market deregulation, macroeconomic variables and stock market performances. International Journal of Trade, Economics and Finance, 2(6), 495-500.

Baranidharan, S. (2016). The dynamic long-run and short-run linkages between exchange rates and BSE Sensex return. IPE Journal of Management, 6(2), 92-105.

Cota, B., Erjavec, N., \& Arneric, J. (2008, June). The impact of macroeconomic variables on Croatian stock market. In An Enterprise Odyssey. International Conference Proceedings, (pp. 70-80) University of Zagreb, Faculty of Economics and Business.

Fama, E. F. (1981). Stock returns, real activity, inflation, and money. The American Economic Review, 71(4), 545-565.

Fama, E. F. (1990). Stock returns, expected returns, and real activity. The Journal of Finance, 45(4), 1089-1108.

Granger, C. W. (1969). Investigating causal relations by econometric models and crossspectral methods. Econometrica: Journal of the Econometric Society, 37(3), 424-438. 
Gupta, R., \& Reid, M. (2013). Macroeconomic surprises and stock returns in South Africa. Studies in Economics and Finance, 30(3), 266-282.

Hussainey, K., \& Khanh Ngoc, L. (2009). The impact of macroeconomic indicators on Vietnamese stock prices. The Journal of Risk Finance, 10(4), 321-332.

Kaur, D. (2009). Correlation and causality between stock market and macroeconomic variables in India: An empirical study. M. Phil. dissertation, Thapar University Patiala. Retrieved from http://dspace.thapar.edu:8080/jspui/bitstream/10266/856/1/Deepinder.pdf

Kwon, C. S., Shin, T. S., \& Bacon, F. W. (1997). The effect of macroeconomic variables on stock market returns in developing markets. Multinational Business Review, 5(2), 6370.

Malkiel, B. G., \& Fama, E. F. (1970). Efficient capital markets: A review of theory and empirical work. The Journal of Finance, 25(2), 383-417.

Mashayekh, S., Moradkhani, H. H., \& Jafari, M. (2011). Impact of macroeconomic variables on stock market: The case of Iran. Journal of Business and Economic Research, 2(2), 350-361.

Menike, L. M. C. S. (2010). The effect of macroeconomic variables on stock prices in emerging Sri Lankan stock market. Sabaragamuwa University Journal, 6(1), 50-67.

Mohi-u-Din, S., \& Mubasher, H. M. (2013). Macroeconomic variables on stock market interactions: The Indian experience. Advances in Management, 6(8), 39-51.

Momani, G. F., \& Alsharari, M. A. (2012). Impact of economic factors on the stock prices at Amman stock market (1992-2010). International Journal of Economics and Finance, 4(1), 151-159.

Pal, K., \& Mittal, R. (2011). Impact of macroeconomic indicators on Indian capital markets. The Journal of Risk Finance, 12(2), 84-97.

Pilinkus, D., \& Boguslauskas, V. (2015). The short-run relationship between stock market prices and macroeconomic variables in Lithuania: An application of the impulse response function. Engineering Economics, 65(5), 26-34. 
Plachý, R., \& Rasovec, T. (2015). Impact of economic indicators on development of capital market. Ekonomie a Management, 18(3), 101-112.

Pramod Kumar, N. A. I. K., \& Puja, P. (2012). The impact of macroeconomic fundamentals on stock prices revisited: An evidence from Indian data. Retrieved from http://mpra.ub.uni-muenchen.de/38980/

Ray, P., \& Vani, V. (2012). What moves Indian stock markets: A study on the linkage with real economy in post-reform era. Retrieved from http://hdl.handle.net/2275/219

Raza, N., Ibrahimy, A. I., Ali, A., \& Ali, S. (2016). Gold and Islamic stocks: A hedge and safe haven comparison in time frequency domain for BRICS markets. The Journal of Developing Areas, 50(6), 305-318.

Roll, R., \& Ross, S. A. (1980). An empirical investigation of the arbitrage pricing theory. The Journal of Finance, 35(5), 1073-1103.

Ross, S. A. (1976). The arbitrage theory of capital asset pricing. Journal of economic theory, 13(3), 341-360.

Singh, G. (2016). The impact of macroeconomic fundamentals on stock prices revised: A study of Indian stock market. Journal of International Economics, 7(1), 76-91

Srinivasan, P. (2011). Causal nexus between stock market return and selected macroeconomic variables in India: Evidence from the National Stock Exchange (NSE). IUP Journal of Financial Risk Management, 8(4), 7-24.

Suganthi, P., \& Dharshanaa, C. (2014). Interrelationship between FII and stock market and their causal relationship with selected macroeconomic variables in India. TSM Business Review, 2(1), 29-46.

Tripathi, V., \&Kumar, A. (2015). Do macroeconomic variables affect stock returns in BRICS markets? An ARDL approach. Retrieved from http://www.publishingindia.com.

Zakaria, Z., \& Shamsuddin, S. (2012). Empirical evidence on the relationship between stock market volatility and macroeconomics volatility in Malaysia. .Journal of Business Studies Quarterly, 4(2), 61-71. 